\title{
Perubahan morfologi larva nyamuk akibat pemberian larvasida bakteri kitinolitik
}

\author{
Morphological changes of mosquito larvae affected \\ by chitinolitic bacteria as larvacide
}

\author{
Yekki Yasmin*, Lenni Fitri
}

Departemen Biologi, Fakultas Matematika dan Ilmu Pengetahuan Alam, Universitas Syah Kuala, Jalan Syekh Abdurrauf No. 3, Darussalam Banda Aceh 23111

(diterima November 2012, disetujui Maret 2013)

\begin{abstract}
ABSTRAK
Penelitian ini bertujuan untuk melihat perubahan morfologi larva Aedes aegypti L. dan Culex spp. akibat pemberian bakteri kitinolitik sebagai larvasida. Penelitian ini bertempat di Laboratorium Mikrobiologi, Fakultas Matematika dan Ilmu Pengetahuan Alam, Universitas Syiah Kuala. Pengambilan sampel air dilakukan di beberapa daerah di Banda Aceh dan Aceh Besar. Isolasi dilakukan dengan mengambil $1 \mathrm{ml}$ sampel air, lalu dicawankan pada media agar kitin dan diinkubasi selama 48-72 jam pada suhu $30^{\circ} \mathrm{C}$. Metode yang digunakan adalah metode eksperimental dengan perlakuan, yaitu konsentrasi bakteri kitinolitik $(0,5,1,0$, dan $1,5 \mathrm{ml})$ dan waktu pengamatan selama 7 hari. Hasil penelitian diperoleh enam isolat yang berpotensi sebagai bakteri kitinolitik. Hasil penelitian juga menunjukkan bahwa bakteri kitinolitik mampu mendegradasi eksoskeleton larva nyamuk $A$. aegypti dan Culex spp. instar II. Kerusakan larva mulai terlihat pada hari ke-4 pengamatan. Kerusakan seluruh eksoskeleton kedua jenis larva terlihat pada hari ke-6.
\end{abstract}

Kata kunci: larva Aedes aegypti L., Culex spp., bakteri kitinolitik

\begin{abstract}
The aim of this research is to evaluate the change of Aedes aegypti L. and Culex spp. larvae morphology effected by chitinolitic bacteria as larvacide. This research was conducted in Microbiology Laboratory, Faculty of Math and Natural Science, University of Syiah Kuala. The sample was taken from several areas in Banda Aceh and Aceh Besar. The isolation was accomplished by plating $1 \mathrm{ml}$ of sample water on chitin agar medium and incubating for $48-72$ hours in $30{ }^{\circ} \mathrm{C}$ temperature. In the experimental method, three concentrations of chitinolitic bacteria $(0.5,1.0$, and $1.5 \mathrm{ml}$ ) in 7 days observation were used as a treatment. The research resulted in 6 isolates having the potential to be developed firther as chitinolitic bacteria. The result shows that chitinolitic bacteria degrades exosceleton of second instar larvae of Aedes aegypti and Culex spp. Degradation of exoskeleton started on the 4th days and occurred at the thorax region. All exoskeleton from both species are completely broken on day six.
\end{abstract}

Key words: Aedes aegypti L. larvae, Culex spp., chitinolitic bacteria

\section{PENDAHULUAN}

Penyakit yang ditularkan oleh serangga hingga saat ini masih merupakan masalah kesehatan di Indonesia, terutama penyakit demam berdarah dengue dan filariasis. Jenis nyamuk vektor penyakit tersebut adalah Aedes aegypti untuk demam berdarah dengue (Soedarmo 2000) dan Culex quinguefasciatus yang merupakan vektor filariasis (Ambarita \& Sitorus 2006). Pengendalian

\footnotetext{
*Penulis korespondensi: Yekki Yasmin. Departemen Biologi, Fakultas Matematika dan Ilmu Pengetahuan Alam, Universitas Syah Kuala, Jalan Syekh Abdurrauf No. 3, Darussalam Banda Aceh 23111

Tel: 0651 7428212, Email: yekkiyasmin@yahoo.co.id 
vektor dilakukan untuk mengurangi atau menekan populasi vektor serendah-rendahnya sehingga tidak berarti lagi sebagai penular penyakit dan menghindari terjadinya kontak antara vektor dan manusia (Sudarmaja \& Mardihusodo 2009).

Pengendalian terhadap vektor penyakit dapat dilakukan dengan cara alami dan buatan. Pengendalian alami meliputi pengendalian yang berhubungan dengan faktor geografis, perubahan musim dan iklim, angin, predator, dan hama, sedangkan dengan cara buatan terdiri atas pengendalian mekanik, kimiawi, fisik, hayati dan genetika (Gandahusada et al. 1998). Pengendalian yang sering dilakukan adalah secara fogging, yaitu pengasapan yang dilakukan terhadap imago (Kusumawati et al. 2007).

Satu diantara cara pengendalian nyamuk dapat dilakukan pada tahap larva. Pengendalian larva nyamuk yang selama ini sering digunakan adalah pengendalian secara kimiawi, yaitu dengan menggunakan zat kimia. Hal ini dapat menekan populasi vektor secara cepat. Namun, pengendalian dengan cara ini bila dilakukan secara berulangulang kurang efektif karena dapat menyebabkan resistensi bagi larva, kematian bagi hewan predator larva dan pencemaran lingkungan (Yunita et al. 2009). Pengendalian hayati pada larva lebih aman dilakukan. Pengendalian hayati terhadap larva nyamuk dapat menggunakan organisme lain, seperti bakteri dan jamur (Widiarti 2005).

Borror et al. (1996) mengatakan bahwa kitin merupakan suatu zat yang sangat resisten, tetapi tidak membuat kutikula keras. Menurut Dewi (2008) kitin dapat larut dalam asam-asam mineral pekat, tetapi tidak larut dalam air. Cahyaningrum et al. (2007) mengatakan bahwa kitin dapat diisolasi dari serangga dan jamur, kerangka dan cangkang hewan golongan Artropoda, Molusca, Nematoda, dan Crustacea.

Penelitian yang dilakukan dengan menggunakan bakteri kitinolitik sebagai pengendali hayati terhadap serangga telah banyak dilakukan, hal ini tidak menutup kemungkinan untuk memanfaatkan bakteri kitinolitik sebagai larvasida hayati bagi nyamuk. Menurut Suryanto et al. (2005) penggunaan bakteri sebagai larvasida nyamuk karena bakteri ini mampu mendegradasi kitin menjadi derivat kitin. Kitin berfungsi untuk morfogenesis dinding sel dan pembangun eksoskeleton nyamuk. Bakteri kitinolitik dapat diisolasi dari air dan tanah.

Banda Aceh dan Aceh Besar memiliki kawasan perairan yang luas. Besarnya potensi perairan di Banda Aceh dan Aceh Besar memungkinkan untuk melakukan isolasi bakteri kitinolitik dari air. Pemberian bakteri kitinolitik dapat menyebabkan kerusakan pada morfologi larva nyamuk. Kerusakan struktur eksoskeleton larva nyamuk akibat pemberian bakteri kitinolitik dapat menyebabkan terganggunya proses pertumbuhan dan metabolisme tubuh nyamuk. Hal ini membuat larva tidak mampu bermetamorfosis. Terganggunya metabolisme tubuh nyamuk ini dapat menyebabkan kematian sehingga dapat mengurangi populasi nyamuk (Pujiyanto et al. 2008). Sampai saat ini, informasi yang didapatkan tentang pengendalian nyamuk menggunakan bakteri ini belum banyak dilaporkan. Oleh karena itu, perlu dilakukan penelitian tentang pengendalian larva nyamuk A. aegypti dan Culex spp. dengan menggunakan bakteri kitinolitik isolat lokal dan membandingkan perubahan morfologi larva yang ditunjukkan akibat pemberian bakteri tersebut.

Penelitian ini bertujuan untuk mengisolasi bakteri kitinolitik isolat lokal yang dapat berfungsi sebagai larvasida hayati A. aegypti dan Culex spp.

\section{BAHAN DAN METODE}

\section{Pemeliharaan larva}

Pengumpulan larva nyamuk $A$. aegypti dilakukan dengan menggunakan ovitrap, sedangkan larva Culex spp. diperoleh dengan melakukan pencidukan di parit dengan menggunakan alat penciduk. Ovitrap berupa kaleng kecil berwarna hitam yang diberi papan sebagai tempat meletakkan telur. Kaleng diisi air sebanyak $10 \mathrm{ml}$. Setelah lima hari air yang terdapat di dalam ovitrap dimasukkan ke dalam wadah pemeliharaan larva. Larva kemudian dipelihara sampai menjadi pupa. Selama pemeliharaan, larva diberi pakan berupa ragi sebanyak $1 \mathrm{~g}$ yang dimasukkan ke dalam wadah pemeliharaan larva. Setiap dua hari air diganti dengan yang baru. Setelah memasuki masa pupa, wadah pemeliharaan larva dimasukkan ke dalam kurungan pemeliharaan imago. Setelah menjadi imago maka imago jantan diberi pakan 
berupa larutan gula $10 \%$, sedangkan imago betina diberikan darah mencit. Pemberian darah mencit dilakukan dengan memasukkan mencit yang telah dicukur bulunya dan diletakkan dalam perangkap mencit ke dalam kurungan pemeliharaan nyamuk selama 1 jam (Yasmin \& Fitri 2010).

Setelah imago berumur 7 hari, dimasukkan kertas saring yang telah dibasahi dan dibentuk, seperti kerucut ke dalam kurungan pemeliharaan. Kertas saring diletakkan pada wadah yang berisi air. Kertas saring ini digunakan sebagai tempat peletakan telur oleh nyamuk betina. Telur yang telah diletakkan oleh nyamuk betina, dimasukkan kembali ke dalam wadah pemeliharaan larva. Telur dibiarkan hingga menetas. Setelah menetas, larva dipelihara hingga mencapai instar II. Sebagian instar II di ambil untuk perlakuan dan sebagian lagi digunakan untuk pemeliharaan selanjutnya (Yasmin \& Fitri 2010).

\section{Pembuatan kitin}

Sampel yang digunakan dalam pembuatan kitin adalah limbah cangkang udang. Cangkang udang dicuci hingga bersih dan dikeringkan di bawah sinar matahari selama 1 hari. Cangkang kering kemudian digiling hingga menjadi serbuk halus. Proses pembuatan kitin selanjutnya meliputi tahap deproteinasi untuk menghilangkan protein dan tahap demineralisasi untuk menghilangkan sisa mineral (Ramadhan et al. 2010).

Tahap deproteinasi. Seratus gram serbuk kulit udang dimasukkan ke dalam erlenmmeyer yang

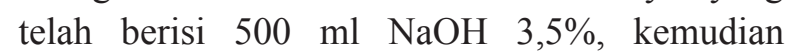
diaduk di atas magnetic stirer selama 2 jam pada suhu $60{ }^{\circ} \mathrm{C}$. Campuran kemudian disaring untuk mendapatkan residunya. Residu dicuci dengan akuades hingga $\mathrm{pH}$ netral dan selanjutnya dikeringkan dalam oven selama 4 jam pada suhu $60{ }^{\circ} \mathrm{C}$ (Ramadhan et al. 2010)

Tahap demineralisasi. Kulit udang kering hasil deproteinasi $(64 \mathrm{~g})$ dilarutkan dalam $\mathrm{HCl} 2 \mathrm{~N}$ sebanyak $640 \mathrm{ml}$. Campuran kemudian didiamkan selama 2 hari pada suhu kamar. Residu yang diperoleh dicuci dengan akuades hingga $\mathrm{pH}$ netral dan dikeringkan kembali dalam oven selama 4 jam pada suhu $60{ }^{\circ} \mathrm{C}$ hingga diperoleh kitin (Ramadhan et al. 2010).

\section{Pembuatan koloid kitin}

Kitin sebanyak 20 g dilarutkan dalam $400 \mathrm{ml}$ $\mathrm{HCl}$ pekat dan disimpan dalam lemari pendingin selama semalam. Larutan disaring kemudian endapan yang terbentuk ditambahkan $200 \mathrm{ml}$ akuades dingin. Larutan kemudian disentrifus dengan kecepatan $4000 \mathrm{rpm}$ selama 15 menit. Residu diambil dan ditambahkan akuades dingin. Larutan kemudian dinetralkan dengan menambahkan $\mathrm{NaOH} 10 \mathrm{~N}$ hingga mencapai $\mathrm{pH}$ 7. Larutan kemudian disentrifus dengan kecepatan $4000 \mathrm{rpm}$ selama 15 menit. Supernatan yang terbentuk dibuang dan endapan ditambahkan kembali dengan akuades dingin sebanyak $200 \mathrm{ml}$ untuk menghilangkan $\mathrm{NaCl}$. Larutan diaduk untuk melarutkan sisa garam dan kemudian disentrifus kembali dengan kecepatan 4000 rpm selama 15 menit. Koloid kitin yang didapat disimpan dalam lemari pendingin (Pujiyanto, tidak dipublikasikan).

\section{Pembuatan media agar kitin}

Media agar kitin terdiri atas $0,5 \%$ koloid kitin, $0,1 \%$ MgSO $4.7 \mathrm{H} 2 \mathrm{O}, \quad 0,02 \% \quad \mathrm{~K} 2 \mathrm{HPO} 4$, $0,1 \%$ ekstrak yeast, dan $1,5 \%$ agar. Bahan media agar kitin dan koloid kitin disterilisasikan dengan menggunakan autoklaf selama 15 menit pada suhu $121{ }^{\circ} \mathrm{C}$ namun pada wadah yang berbeda. Kemudian setelah dingin, koloid kitin dicampur dengan bahan media agar kitin lain dalam keadaan steril. Media agar kitin steril dituang ke dalam cawan petri. Media kemudian disimpan dalam inkubator dengan posisi terbalik sebelum digunakan (Pujiyanto et al. 2008).

\section{Isolasi dan seleksi bakteri}

Bakteri kitinolitik diisolasi dari sampel air, yaitu air laut, tambak dan sungai yang diambil di beberapa tempat di daerah Banda Aceh dan Aceh Besar. Sampel air laut diperoleh dari laut Ujung Kareung, Ulee Lheue, Syiah Kuala dan Alue Naga. Sampel air tambak diambil dari tambak Tibang, Deah Raya, Deah Baro dan Baet. Sampel air sungai diambil dari sungai Lamnyong, Krueng Aceh, Krueng Daroi dan Krueng Raba.

Sebanyak $1 \mathrm{ml}$ sampel air dimasukkan kedalam cawan petri yang telah berisi media agar kitin dan diinkubasi selama 48-72 jam pada suhu $30{ }^{\circ} \mathrm{C}$. Setelah bakteri tumbuh dilakukan seleksi dengan melihat bakteri yang menghasilkan zona 
bening. Kemudian dilakukan purifikasi isolat untuk mendapatkan isolat murni. Isolat yang diperoleh digunakan untuk uji hayati dan disimpan pada suhu $4{ }^{\circ} \mathrm{C}$ untuk pemeliharaan (Pujiyanto et al. 2008).

\section{Uji hayati}

Larva nyamuk $A$. aegypti dan Culex spp. dimasukkan dalam wadah pemeliharaan berdiameter $20 \mathrm{~cm}$ sebanyak 10 individu dalam $150 \mathrm{ml}$ air. Biakan bakteri yang sudah didapatkan dimasukkan sebanyak $0,5,1$, dan 1,5 $\mathrm{ml}$ ke dalam wadah uji dan diamati jumlah larva nyamuk yang mati sebelum serta selama 7 hari pengamatan (Pujiyanto et al. 2008). Parameter yang diamati adalah morfologi larva nyamuk sebelum perlakuan dan selama 7 hari pengamatan.

\section{HASIL}

Hasil pengamatan terhadap larva $A$. aegypti dan Culex spp. yang diberi perlakuan bakteri kitinolitik menunjukkan kerusakan eksoskeleton larva pada tingkat konsentrasi $1,5 \mathrm{ml}$. Pada pemberian bakteri kitinolitik konsentrasi 0,5 dan $1 \mathrm{ml}$ kematian larva nyamuk terjadi, tetapi kerusakan eksoskeleton tidak terjadi sehingga pengamatan morfologi larva yang diberikan bakteri kitinolitik diamati pada konsentrasi 1,5 ml.

Larva nyamuk yang digunakan pada penelitian ini adalah larva A. aegypti dan Culex spp. instar II. Perbedaan kedua jenis larva ini terlihat pada sifon dan gigi sisir yang terdapat di segmen ke-8 larva. Larva Culex spp. umumnya memiliki sifon yang lebih panjang dan ramping dibandingkan dengan larva A. aegypti (Gambar 1).

Kematian larva $A$. aegypti terjadi mulai dari hari pertama pengamatan, sedangkan larva Culex spp. terjadi pada hari ke-3 pengamatan (Gambar 2). Morfologi larva yang mati pada hari ke-4 berbeda dengan yang mati pada hari sebelumnya. Pada hari ke-4 kerusakan morfologi larva A. aegypti terlihat di bagian toraks, sedangkan larva Culex spp. terlihat di bagian abdomennya (Gambar 3).

Morfologi larva pada hari ke-6 menunjukkan kerusakan pada bagian caput, toraks dan abdomen (Gambar 4). Kerusakan tubuh larva A. aegypti pada hari ke-6 terjadi pada semua bagian tubuh larva dan hanya terlihat saluran pencernaannya.
Kerusakan pada larva Culex spp. tidak jauh berbeda dengan $A$. aegypti, namun pada Culex spp. masih terlihat bagian caput.

Isolat yang paling banyak menimbulkan kerusakan eksoskleton larva $A$. aegypti dan Culex spp. adalah isolat dari sungai Lamnyong (L4). Larva $A$. aegypti lebih banyak mengalami kematian dibandingkan dengan Culex spp. (Tabel $1)$.
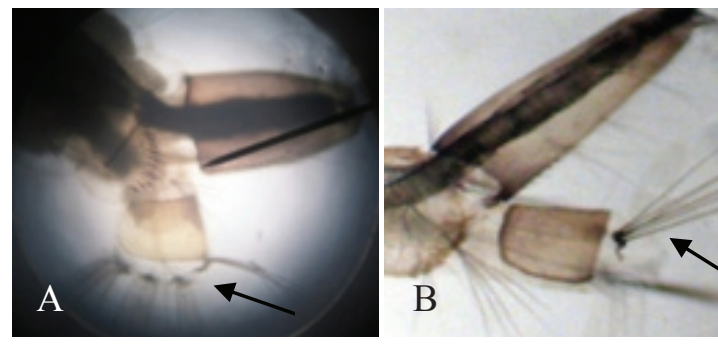

Gambar 1. Sifon pada larva nyamuk (tanda panah): A: Aedes aegypti; B: Culex spp.
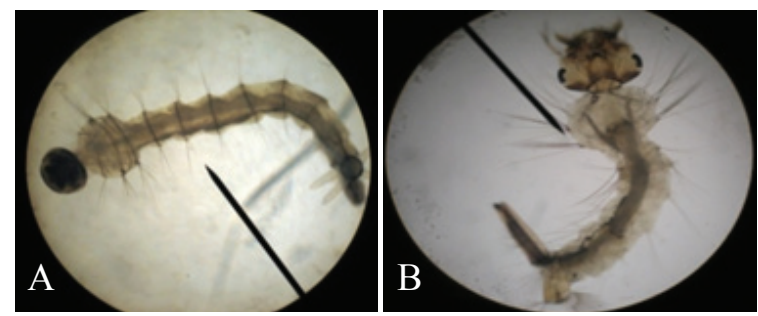

Gambar 2. Larva nyamuk yang mati: A: Aedes aegypti pada hari ke-1; B: Larva Culex spp. pada hari ke-3.

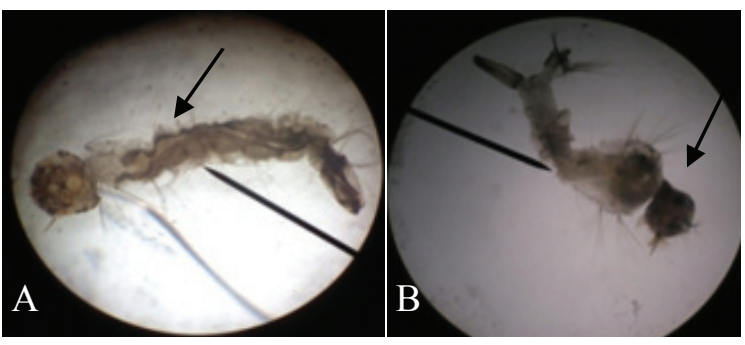

Gambar 3. Larva nyamuk yang mati pada hari ke-4: A:Aedes aegypti; B:Culex spp. Kerusakan ditunjukan dengan tanda panah.

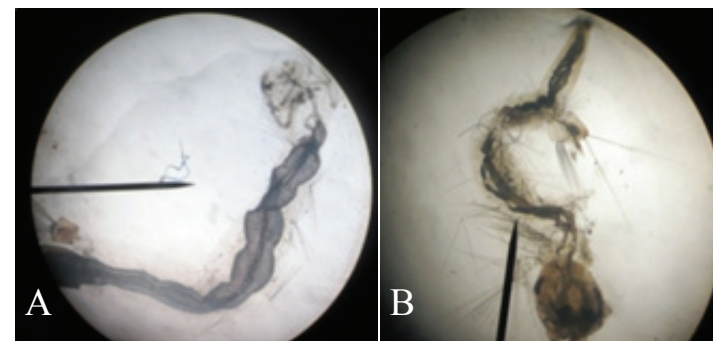

Gambar 4. Larva nyamuk yang mati pada hari ke-6: A: Aedes aegypti; B: Culex spp. 
Tabel 1. Jumlah kematian larva pada hari ke-7 hari pengamatan

\begin{tabular}{|c|c|c|c|c|c|c|}
\hline \multirow{3}{*}{ Sumber Isolat } & \multicolumn{6}{|c|}{ Jumlah larva mati (individu) } \\
\hline & \multicolumn{3}{|c|}{ Aedes aegypti } & \multicolumn{3}{|c|}{ Culex spp. } \\
\hline & $0,5 \mathrm{ml}$ & $1 \mathrm{ml}$ & $1,5 \mathrm{ml}$ & $0,5 \mathrm{ml}$ & $1 \mathrm{ml}$ & $1,5 \mathrm{ml}$ \\
\hline Alue Naga (AN1) & 0 & 1 & 1 & 0 & 1 & 0 \\
\hline Syiah Kuala (SK3) & 0 & 0 & 3 & 0 & 0 & 1 \\
\hline Baet (B5) & 1 & 0 & 1 & 0 & 0 & 1 \\
\hline Deah Raya (DR3) & 0 & 2 & 1 & 0 & 0 & 1 \\
\hline Lamnyong (L4) & 1 & 1 & 5 & 0 & 0 & 2 \\
\hline Krueng Raya (KR3) & 1 & 1 & 2 & 0 & 1 & 0 \\
\hline
\end{tabular}

\section{PEMBAHASAN}

Kerusakan eksoskeleton larva yang terjadi pada pemberian bakteri kitinolitik dengan konsentrasi $1,5 \mathrm{ml}$ diduga karena pada konsentrasi tersebut terdapat jumlah bakteri kitinolitik yang lebih banyak dibandingkan dengan konsentrasi lainnya sehingga lebih mampu dalam merusak eksoskeleton larva nyamuk. Hal ini sejalan dengan penelitian Pujiyanto et al. (2008) yang mengatakan bahwa semakin tinggi konsentrasi inokulum bakteri yang diberikan maka semakin tinggi tingkat kematian larva.

Pemilihan larva instar II bagi kedua jenis nyamuk ini akan lebih mudah terpapar bakteri kitinolitik. Sanjaya \& Safaria (2006) mengatakan bahwa semakin dewasa larva maka daya tahan tubuhnya semakin tinggi. Hal ini disebabkan oleh lapisan kulit larva instar empat jauh lebih tebal daripada larva instar satu.

Perilaku larva sebelum diberi perlakuan umumnya tidak berbeda antara $A$. aegypti dan Culex spp., yaitu aktif berenang, makan, istirahat di permukaan air dan berputar-putar. Setelah perlakuan terlihat perbedaan perilaku antara kedua jenis larva. Larva $A$. aegypti terlihat berkurang keaktifannya pada hari pertama pengamatan, namun larva Culex spp. terlihat lebih aktif berenang. Hal ini dilihat dari gerakan-gerakan larva $A$. aegypti yang menjadi lambat. Hal ini sesuai dengan penelitian Yasmin \& Fitri (2010) yang mengatakan bahwa larva $A$. aegypti terlihat melambat setelah pemberian mikroorganisme sebagai larvasida.

Perbedaan hari kematian antara kedua jenis larva diduga karena larva Culex spp. lebih tahan terhadap bakteri kitinolitik dibandingkan dengan larva $A$. aegypti. Hal ini sejalan dengan penelitian Widiyanti \& Muyadihardja (2004) yang mengatakan bahwa nyamuk Culex spp. sudah resisten terhadap berbagai bahan aktif insektisida jika dibandingkan dengan nyamuk $A$. aegypti.

Pada hari keempat, kerusakan eksosokeleton larva dari kedua nyamuk ini diduga karena bakteri kitinolitik telah merusak kerangka luar larva. Menurut Jumar (2000), eksoskeleton adalah dinding tubuh yang berfungsi sebagai kerangka luar serangga. Kerusakan eksoskeleton larva ini diduga karena bakteri kitinolitik telah mendegradasi kitin yang merupakan struktur penyusun eksoskeleton larva nyamuk. Kitin pada larva berfungsi sebagai pelindung tubuh dan mekanisme utama dalam membatasi kehilangan air melalui dinding tubuh (Borror et al. 1996). Hal ini sejalan dengan penelitian Yunita et al. (2009) yang mengatakan bahwa dinding tubuh serangga merupakan bagian tubuh yang mudah menyerap zat toksik. Menurut Nasran et al. (2003), bakteri kitinolitik mampu menghasilkan enzim kitinase yang mampu mendegradasi kitin dengan memutuskan ikatan glikosidiknya.

Banyaknya bagian tubuh larva yang rusak pada hari keenam pengamatan menunjukkan bahwa semakin lama larva terpapar oleh bakteri kitinolitik maka seluruh struktur eksoskeleton larva semakin rusak. Kemampuan bakteri kitinolitik isolat Lamnyong dalam membunuh larva diduga karena isolat ini merupakan bakteri yang berasal dari sungai. Sungai memiliki salinitas yang hampir sama dengan akuades yang digunakan pada uji hayati. Oleh karena itu, kemampuan bakteri hidup di akuades lebih tinggi daripada bakteri yang diisolasi dari air laut dan tambak yang memiliki salinitas yang berbeda dengan akuades sehingga bakteri hasil isolat sungai lebih aktif dalam membunuh larva. 


\section{KESIMPULAN}

Bakteri kitinolitik mampu merusak eksoskeleton larva $A$. aegypti dan Culex spp. Kerusakan struktur eksoskeleton pada larva $A$. aegypti dan Culex spp. mulai terlihat pada hari keempat pengamatan. Kerusakan seluruh struktur eksoskeleton kedua jenis larva terlihat pada hari ke-6 pengamatan. Penelitian lanjutan dengan menggunakan isolat bakteri kitinolitik dari sumber lain dan diaplikasikan pada jenis nyamuk lain perlu dilakukan.

\section{DAFTAR PUSTAKA}

Ambarita LP, Sitorus H. 2006. Studi komunitas nyamuk di Desa Sebubus (daerah endemis Filariasis), Sumatera Selatan tahun 2004. Jurnal Ekologi Kesehatan 5:368-375.

Borror DJ, Triplehorn CA, Johnson NF. 1996. Pengenalan Pelajaran Serangga Edisi ke-6. S. Partosoedjono, penerjemah. Yogyakarta: Gajahmada University Press. Translation of: $A n$ Introduction to the Study of Insect.

Cahyaningrum SE, Agustini R, Herdyastuti N. 2007. Pemakaian kitosan limbah udang windu sebagai matriks pendukung pada imobilisasi papain. Akta Kimindo 2:93-98.

Dewi IM. 2008. Isolasi Bakteri dan Uji Aktivitas Kitinase Termofilik Kasar dari Sumber Air Panas Tinggi Raja Simalungun Sumatera Utara. Master Thesis. Medan: Universitas Sumatera Utara.

Gandahusada S, Ilahude HD, Wita P. 1998. Parasitologi Kedokteran. Edisi ke-3. Jakarta: Universitas Indonesia.

Jumar. 2000. Entomologi Pertanian. Jakarta: PT. Rineka Cipta.

Kusumawati Y, Suswardhany DL, Yuniarto S, Darnoto S. 2007. Upaya pemberantasan nyamuk Aedes aegypti dengan pengasapan (fogging) dalam rangka mencegah peningkatan kasus demam berdarah. Jurnal Warta 10:1-9.

Nasran S, Afriyani F, Indriat N. 2003. Produksi kitinase dan kitin deasetilase dari Vibrio harveyi. Jurnal Penelitian Perikanan Indonesia 9:33-38.
Pujiyanto S, Kusdiyanti E, Hadi M. 2008. Isolasi dan seleksi bakteri kitinolitik isolat lokal yang berpotensi untuk mengendalikan larva nyamuk Aedes aegypti L. Jurnal Biodiversitas 9:5-8.

Ramadhan LOAN, Radiman CL, Wahyuningrum D, Suendo V, Ahmad LO, Valiyaveetiil S. 2010. Deasetilasi kitin secara bertahap dan pengaruhnya terhadap derajat deasetilasi serta massa molekul kitosan. Jurnal Kimia Indonesia 5:1721.

Sanjaya Y, Safaria T. 2006. Toksisitas racun labalaba Nephila sp. pada larva Aedes aegypti L. Biodiversitas 7:191-194.

Soedarmo SP. 2000. Masalah demam berdarah dengue di Indonesia. In: Sri RHH, Hindra IS (Eds.), Buku Naskah Lengkap Demam Berdarah Dengue; Pelatihan bagi Pelatih Dokter Spesialis Anak dan Dokter Spesialis Penyakit Dalam dalam Tatalaksana Kasus DBD. Edisi ke-2. pp: 1-13. Jakarta: Balai Penerbit FKUI.

Sudarmaja IM, Mardihusodo SJ. 2009. Pemilihan tempat bertelur nyamuk Aedes aegypti pada air limbah rumah tangga di Laboratorium. Jurnal Veteriner 10:205-207.

Suryanto D, Munir E, Yurnaliza. 2005. Ekplorasi Bakteri Kitinolitik: Keragaman Genetik Gen Penyandi Kitinase pada Berbagai Jenis Bakteri dan Pemanfaatannya. Laporan Hasil Penelitian Hibah Bersaing Perguruan Tinggi Tahun Anggaran 2005. Medan: Universitas Sumatera Utara.

Widiarti. 2005. Uji mikroplat aktivitas enzim esterase untuk mendeteksi resisten Anopheles aconitus terhadap insektisida Organofosfat. Jurnal Kedokteran Yarsi 13:1-10.

Widiyanti NLPM, Muyadihardja S, 2004. Uji toksisitas jamur Metarizhium anisopliae terhadap larva nyamuk Aedes aegypti. Media Litbang Kesehatan 14:25-30.

Yasmin Y, Fitri L, 2010. The effect of Metharrizium anisopliae fungi on mortality of Aedes aegypti L. larvae. Jurnal Natural 10:32-35.

Yunita EA, Suprapti NH, Hidayat JW. 2009. Pengaruh ekstrak daun teklan (Eupatorium riparium) terhadap mortalitas dan perkembangan larva Aedes aegypti. Jurnal Bioma 11:11-17. 